\title{
Luis Fernando Baron: \\ More than a Facebook revolution: Social Movements and Social Media in the Egyptian Arab Spring
}

\begin{abstract}
:
Public opinion leaders and activists characterized the Egyptian "Arab Spring" of January 2011 as a "Facebook Revolution". They highlight the intrinsic power of social media as an influencing factor for social change. Undeniably, social media played important roles in that revolution process. However, these roles cannot be disconnected from the socio-political contexts. This paper discusses the use of social media, particularly of Facebook, by the April 6th Youth Movement (A6YM), a decisive actor of the Egyptian protests. It is based on the analysis of two Egyptian newspapers and one American newspaper, between 2008 and 2011. We propose that a) social media provided alternative mechanisms for political expression and organization, b) social media contributed to the genesis and consolidation of the A6YM and to the establishment of youth political identities, and c) the combination of "bits and streets" amplified not just the movement's mobilization but the degree of opposition experienced by the Egyptian regime.
\end{abstract}

\section{Agenda:}

Introduction .86

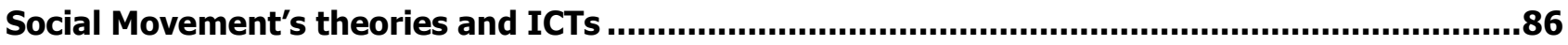

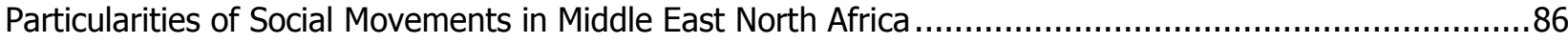

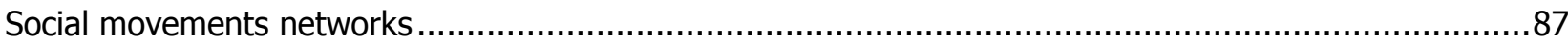

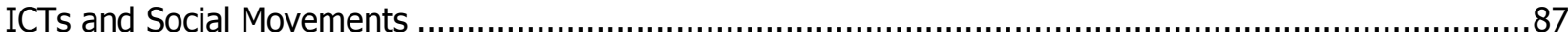

Research Methods.............................................................................................................87

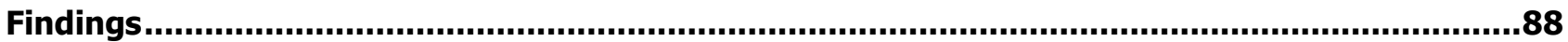

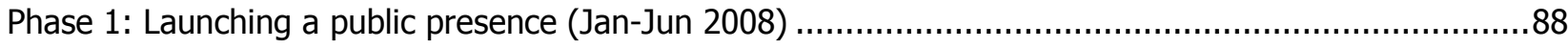

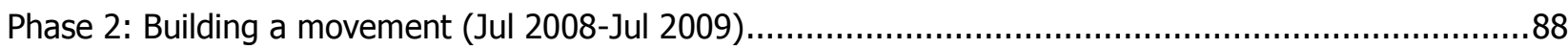

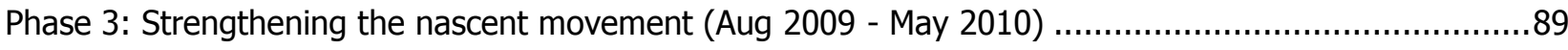

Phase 4: A common grievance: the police brutality (Jun 2010-Dec 2010)........................................ 89

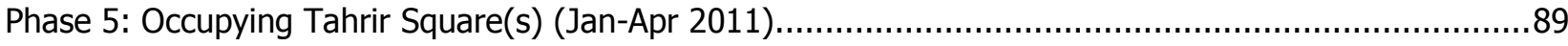

Discussion and Conclusions ..................................................................................................90 


\section{Author(s):}

\section{Luis Fernando Baron}

- Lecturer, Universidad Icesi, Colombia, and Doctoral Candidate Information School University of Washington

- 푱 + 1-206-484-7696, Box 352840, Seattle, WA 98195, USA, Ifbaron@uw.edu

- Relevant publications:

- Baron, L. F., \& Gomez, R. (2012). El Sentido de Conexidad y el Acceso Público a TIC. Disertaciones, 5(1), 23.

- Baron, L. F., \& Valdes, M. (2011). Public Access ICT in Colombia. In R. Gomez (Ed.), Libraries, Telecentres, Cybercafes and Public Access to ICT: International Comparisons (pp. 169-183): IGI Global.

- Gomez, R., \& Baron, L. F. (2011). Does public access computing really contribute to community development? Lessons from libraries, telecenters and cybercafés in Colombia. EJISDC, 49. 


\section{Introduction}

Journalists, Egyptian activists, and even scholars have often characterized the protests which started in Egypt on January 25, 2011, as a "Facebook revolution". This label highlights the intrinsic power of social media ${ }^{1}$ and the potentiality of Web access for democratization and social change. ${ }^{2}$ The use of ICTs (including social media) played a key role before, during, and after the events that took place in Tahrir Square in January and February 2011. However, the roles of social media should not be disconnected from regional and international sociopolitical contexts. One must also consider the history of social protests and social movements in Egypt, as well as the role of youth networks and organizations.

The role of social media should not be studied without acknowledging the multi-decade effort by Muslim organizations in building a social movement or the increasing dynamics of workers' mobilization - which involved over 2 million workers in approximately 3,300 collective actions from 1998 to 2009. Nor can the emergence of new forms of political expression - which have their roots in solidarity committees that spread throughout Egypt following the start of the Second Intifada in Palestine in October 2000 - be ignored. Social media should be considered within the context of regional dynamics such as the revolutions in Iran (2009) and Tunisia (2010), as well as the human rights campaigns launched by local and international organizations in Middle East North Africa (MENA), and the international pressure for political reforms that Mubarak's regime experienced coming from the United States and several European Union countries. This paper will examine the relationships between social media and social movements, considering some of these circumstances so as to construct a more nuanced perspective of the Egyptian "Arab Spring". In particular, this work aims to shed light on how the access to and interactions with and through ICTs shaped the formation, development, and sociopolitical performance of A6YM.

We utilized alternative approaches to Social Movement Theories (SMT) (e.g. Bayat, 2010; Earl \& Kimport, 2011; Escobar, 2008; Melucci, 1994) that challenge institutional perspectives such as Collective Action, Resource Mobilization and Political Opportunity Structures. These approaches help us to interpret the results of a content analysis of a sample of news on social media use as reported by two Egyptian, English-Language newspapers (Al-Ahram and The Daily News Egypt) and one American newspaper (The New York Times), from April 2008 to April 2011. In using these theoretical frameworks and research methods, five analytical stages of the A6YM were identified. The drafted trajectory suggests the use of ICTs was not only significant to the creation and consolidation of this social movement, but that it also played a key role in reporting, framing, and discussing sociopolitical mobilization in Egypt. ICTs were also vital in the call to action, organization, and operation of the protests, and they provided daily life venues for youth identification and political engagement. ICTs materialize alternative arenas of political debate and action, and this has shown to both threaten Hosni Mubarak's regime and shape its political and military responses.

\section{Social Movement's theories and ICTs}

\section{Particularities of Social Movements in Middle East North Africa}

Bayat (2010) has shown that current SMT cannot effectively explain the intricate dynamics of the resistance and upheavals of the MENA. Beinin \& Vairel (2011) also point out that SMT have studied social movements in

\footnotetext{
1 Borrowing from Kaplan \& Haenlein, Social Media are understood here as the group of Internet-based applications that allow the creation and exchange of user-generated content. These authors categorize social media in six groups: collaborative projects (e.g. wikis); blogs and microblogs (e.g. Twitter); content communities (e.g. YouTube); social-networking sites (e.g. Facebook); virtual game worlds (e.g. World of Warcraft), and virtual social worlds (e.g. Second Life). Kaplan, A. M., \& Haenlein, M. (2010). Users of the world, unite! The challenges and opportunities of Social Media. Bus. Horiz. Business Horizons, 53(1), 59-68.
}

2 For example: HTTP://WWW.TECHNOLOGYREVIEW.COM/BLOG/EDITORS/26718/; http://www.huffingtonpost.com/2011/02/11/egyptfacebook-revolution-wael-ghonim_n_822078.html; http://www.time.com/time/world/article/0,8599,2044142,00.html 
MENA with an exceptionalist approach, which does not adequately explain the intricacies of persisting authoritarianisms that subject social movements to varying degrees of coercion and offer them few openings for mobilization. Bayat underlines the importance of 'non-movements' as collective actions of non-collective actors and explains how urban public spaces, particularly streets, continue to serve as a key theater of contentions. He also underlined the importance of the relative spaces of freedom in contexts such as Egypt (Bayat, 2010).

\section{Social movements networks}

In the early 1990's, Melucci (1994) demonstrated how movements are media that speak through action; their primary message is that they exist and act. The action of movements can be seen as symbolic and as communication. Social movements are intricate networks of individual and collective agents (humans and non-humans) that constitute a wave of confrontational social engagements at many levels that encompass different forms of performances and associations marked by their oppositional but proactive character (Escobar, 2008; Melucci, 1994). Following Latour we could say that they are not the foundations but rather the results of the same networks' associations (Latour, 2007).

\section{ICTs and Social Movements}

Earl \& Kimport (2011) provide evidence of the ways ICTs have impacted the creation and development of collective actions. They point out three key aspects: 1) the coexistence in time and space of collective participation; 2) the ephemeral, sporadic, episodic, or enduring characteristics of contention; and 3) the evidence of the existence of challenges and challengers without movements. Those changes not only have challenged social movements' scholars to create or modify existing theoretical lenses for understanding what collective action is, but they also have stimulated different approaches to understanding how ICTs are affecting social movements, political practices, and power processes (e.g. Bennett, Breunig, \& Givens, 2008; B. Bimber, Flanagin, \& Stohl, 2005; B. A. Bimber, 2003; Howard, 2010).

\section{Research Methods}

This paper is part of a larger study on the changing roles of social media in pro-democracy movements in Egypt by the Technology \& Social Change Group (TASCHA) at the University of Washington's iSchool. ${ }^{3}$ The larger study includes content analysis of blogs and Facebook pages in Arabic and English, regional news media ( $A /$ Jazeera), and interviews with key actors in Egypt. This paper is based on the analysis of a sample of more than 250 articles on protests and social mobilization of three English-language newspapers (The Daily News Egypt, Al-Ahram, and The New York Times) from April 2008 (the genesis of A6YM), to April 2011 (the Tahrir Square protests which produced Mubarak's resignation). The newspapers were selected based on the following criteria: a) covers local and international news; b) includes state and independent approaches; c) offers accessibility through the Internet; and d) provides access to English-language sources. The Daily News Egypt (DNE) is an independent, privately owned newspaper which was affiliated with the International Herald Tribune (IHT). The Al-Ahram is a weekly, English-language newspaper run by the Al-Ahram Organization in which the Egyptian government owns a controlling share of the stocks of the paper. The New York Times is a global, multimedia news and information company which includes The New York Times, the International Herald Tribune and The Boston Globe, to mention only a few of its related properties. For selecting articles as well as coding and analyzing them, we used and adapted a framework suggested by Garrido (2006). Thus, we used these categories: a) actors and networks, b) strategies and tactics, c) local and international contexts, and d) uses of social media. 


\section{Findings}

The newspapers' analysis allowed us to define the following five phases of the April 6 Youth Movement (A6YM). These phases are marked by key events which implied different, but not exclusive, uses of social media, which must be considered in relation to socio-political contexts and their interactions with other communication forms and media.

\section{Phase 1: Launching a public presence (Jan-Jun 2008)}

During the Spring of 2008, Egyptian workers and other opposition groups and movements ${ }^{4}$ called for a national strike on April $6^{\text {th }}$ at Ghazl Al-Mahalla textile factory. This call sprung out of municipal elections and the increasing social protests marked by the "bread crisis" (the price upsurges in essential foodstuffs) (El-Fiqi, 2008), and demonstration for raising wages. In March 2008, Israa Abdel-Fattah and Ahmed Maher set up the "April 6 Strike Group" on Facebook, inviting friends to support the workers strike and calling for a nationwide campaign of civil disobedience. The outcome was unexpected: roughly 77,000 people joined the group and committed to either express themselves or stay away from work on April $6^{\text {th. }}$ (Sarah Carr, 2008b; Singer, 2008). The protests of April $6^{\text {th }}$ became a hallmark of social mobilization (Sarah Carr, 2008a) and an expression of the resurgence of the labour movement (Sara Carr, 2008).

In this phase, Facebook and text messages via mobile phones served as tools to extend messages of solidarity and promote a continued commitment to protests of other social movements (mainly of factory workers). They were also used to encourage individual expression of ideas and to create spaces for political debate, especially among young people. Even though participants appear to have been mainly from privileged sectors of Egyptian society, protesters also used other media (such as leaflets, banners and word of mouth) in order to get other social sectors involved

\section{Phase 2: Building a movement (Jul 2008-Jul 2009)}

"We are debating ways to best use Facebook to organize activities." Interview of A. Maher (El-Sayed, 2008)

Despite growing repression measures and constant threats against opposition groups and "Facebook activists" the youth collective was determined to transform their Facebook group into a political movement (El-Sayed, 2008) and to involve more young people and organizations through symbolic expressions of social discontent in key places and moments. Both Israa Abdel-Fattah and Ahmed Maher were imprisoned and tortured by security forces as a result of their "April $6^{\text {th }}$ Strike Group" initiative, which exemplified an increasing awareness of the state institutions on the power of Internet-based technologies -- especially Facebook and blogs -- for mobilization..

At this stage social media, particularly blogs and Web sites, were used to report and discuss on the current events and on social-mobilization activities. Facebook played an important role not only in the call to action and organization of the protests, but it also served to create a space of political conversation. Moreover, it was a key reference platform that helped to identify the nascent social movement, and it became one of the hallmarks of A6YM. Twitter came into the local spotlight on 2008 when journalist James Buck used it to report his arrest after the April $6^{\text {th }}$ protests in Mahalla. (Abdoun, 2009)

\footnotetext{
4 Some reports mentioned the participation of the Labor Party, the Karama Party and Kefaya. They also mentioned that the Muslim Brotherhood did not officially support the strike. See an example in: Carr, S. (2008). State security mobilizes ahead of April 6 general strike, says activist. The Daily News Egypt, p. 1. Retrieved from http://www.masress.com/en/dailynews/102028
} 


\section{Phase 3: Strengthening the nascent movement (Aug 2009 - May 2010)}

The protests and social discontent with the regime grew during this time (Sarah Carr, 2008a; Reem 2008), and A6YM won an important spot within the Egyptian socio-political scenarios. The movement not only became an important bridge between different social organizations but was also the target of pressure and persecution by the state institutions (Singer \& Samaan, 2008).

"What started out as a forum for people to catch up with old friends, upload and share photos, exchange messages and videos and kill many hours of boredom... took a new turn in 2008, particularly on Sunday April 6... The users of Facebook have turned the popular entertainment website into a platform for political activism and promoting social change on different levels. " (Abdoun, 2008)

In this phase, Facebook were transformed into an important subject/object of the political disputes, in a context of increasing normative controls and restrictions by the regime. Social media were mainly used for the dissemination and adoption of these technological tools between oppositional social organizations. Social media were acknowledged by activists as tools for expression and action that have the power to threaten the regime. The events in Iran in July 2009 also brought international notice to the role of social media in a region where citizens were often unable to express their opinions freely (Abdoun, 2009).

\section{Phase 4: A common grievance: the police brutality (Jun 2010-Dec 2010)}

At this stage the narratives of media reflect a general state of frustration with the results of protests and mobilizations in Egypt (Al Malky, 2009). Society, in general, and youth population, in particular, did not expect social or political changes in Egypt (El-Bey, 2010) $)^{5}$. However, the torture and later death of Khaled Saeed by the hands of Egyptian policemen catalyzed a new momentum for social protests and greater public concern of Egypt's political situation. After Saeed's assassination, two Facebook pages, created by activists, gathered an estimated 200,000 supporters in a couple of weeks. ${ }^{6}$ The case not only provided a new impetus to the youth movements (Elyan, 2010), it also triggered new claims of human-rights violations from organizations such as Amnesty International and new calls from the U.S. government and the European Union urging democratic reforms in Egypt. Facebook was very important in building a common narrative about police brutality, but it also became a venue of convergence for multiple political-opposition organizations. Twitter had a significant role in the dissemination of news and organization details of protests, and oppositional blogs continued confronting the regime's versions of the socio-political situation.

\section{Phase 5: Occupying Tahrir Square(s) (Jan-Apr 2011)}

"We will take to the streets to demand the right to life, liberty and dignity and we call on everyone to take to the streets" (...)"The barriers of fear must be broken." (Shehab, 2011)

Three events triggered the protests in Egypt in January 2011: the increasing discontent among the population generated by the results of the second round of Parliamentary Elections on 5 December 2010; the continuing police brutality, epitomized by police repression of the protests following a car bombing during a New Year's Eve service at the al-Qiddissin Church; and the Tunisian revolution as a result of a wave of social and political unrest and civil disobedience. Around these three issues, social organizations and non-collective actors led by a group of youth organizations, including A6YM, framed their messages and called for a national protest on Police Day that culminated in the occupation of Tahrir Square and Mubarak's resignation.

5 This article is based on the Egypt Human Development Report (EHDR) that pointed out that the majority of youth saw political activities as useless and incapable of making a difference to their most immediate problems.

6 This was the data provided within two articles of the Daily News Egypt on June 20, 2010. 
If Tahrir Square could represent the symbolic epicentre of the physical protests during the Egyptian unrest, Facebook could represent the vertebral spine of the network of places created by civil society (majoritarian youth people) for expressing, communicating, informing, networking, and mobilizing against the Mubarak regime. Social media -- in particular, Facebook, YouTube, Twitter and text messages -- were central to initiating the protests, for reporting on the events and coordinating the protests and for building bridges which favoured the interaction between protesters and other social sectors of the Egyptian society and the international community as well as mass media. They were also central tools in the process of framing the public messages that emphasized a) the ability and opportunity for the Egyptians to produce social change, b) the importance of mobilization and taking to the streets, c) the protests as legitimate ways to obtain political reforms, and d) young Egyptians as leading that historical process.

\section{Discussion and Conclusions}

After following the journey of A6YM through the lens of these newspapers, three major findings emerge. Social media did not just provide alternative mechanisms to spread messages and join people in a repressive climate; they also increased the size, speed, and reach of activism (local and internationally). Second, social media not only had an impressive impact on the creation, development, and consolidation of A6YM, but they also became a symbol of the A6YM process of building its own identity. The use of social media also became a sign of identification for youth movements and organizations in Egypt; the combination of 'bits and streets' (online and offline activities, online and offline communications forms), supersized not just the mobilizations but also the size of the threats that Mubarak's regime experienced during the revolutionary dynamic.

One of the most remarkable features of A6YM was its ability to frame and communicate messages that appeal not only to younger people but also other social movements, political parties, and the general public. They also achieved good support from international networks, especially from Internet activists and human-rights organizations. The A6YM movement did an amazing job taking individual and sectorial grievances and transforming them into collective grievances. And social media's speed as well as the narratives their platforms allowed to create had a strong impact on the way the movement framed those collective grievances. The movement was not only good with words, but it also showed great creativity in the planning of the demonstrations. The selection of venues and clothing worn had great symbolic value and were understandable for most of the Egyptian society and well received internationally. Social media was also decisive in the process of building not only a network of individuals and organizations but also a network of socio-political ideas and common strategies to confront the status quo.

A6YM members not only used social media during its socio-political trajectory, they also demonstrated that this media were determinant in shaping the organization and the social interactions the movement had with other social movements and social sectors as well as with the Mubarak regime. Social media also provided different alternatives for people to express and to participate both within the movement and during protests, offering both active and passive levels of engagement.

The aspects mentioned above cast a series of questions and academic challenges. It is necessary to delve into the social spaces created by Internet-based technologies for new social expression and mobilizations of collective and non-collective actors. It is also important to inquire about the ways this and other new movements are framing their collective grievances and how they have been received by other social organizations and different sectors of Egyptian society and the international community. It is worth taking a closer look at the effect social media had in the organization of the movement and its way of dealing with different social situations and the effects social mediahad on the State's response to the growing phenomenon of social mobilization and use of Internet-based technologies. 


\section{References}

Abdoun, S. (2008). The power of Facebook takes new shape in 2008. The Daily News Egypt, p. 1. Retrieved from http://www. masress.com/en/dailynews/114325

Abdoun, S. (2009). Did you tweet today? The Daily News Egypt, p. 1. Retrieved from http://www.thedailynewsegypt.com/did-you-tweet-today.htm/

Al Malky, R. (2009). The death of youth activism in Egypt? The Daily News Egypt, p. 1. Retrieved from http://www.thedailynewsegypt.com/editorial-the-death-of-youth-activism-in-egypt.htm/

Bayat, A. (2010). Life as politics : how ordinary people change the Middle East. Stanford, Calif:: Stanford University Press.

Beinin, J., \& Vairel, F. (2011). Social movements, mobilization, and contestation in the Middle East and North Africa. Stanford, California: Stanford University Press.

Bennett, L., Breunig, C., \& Givens, T. (2008). Communication and Political Mobilization: Digital Media and the Organization of Anti-Iraq War Demonstrations in the U.S. Political Communication, 25(3), 269-289.

Bimber, B., Flanagin, A. J., \& Stohl, C. (2005). Reconceptualizing Collective Action in the Contemporary Media Environment. Communication Theory, 15(4), 365-388.

Bimber, B. A. (2003). Information and American democracy : technology in the evolution of political power. Cambridge, UK; New York: Cambridge University Press.

Carr, S. (2008a). April 6 strike kicks off a year of protests. The Daily News Egypt, p. 1. Retrieved from http://www.masress.com/en/dailynews/100950

Carr, S. (2008b). Is it time to sign out of Facebook? The Daily News Egypt, p. 1. Retrieved from http://www.masress.com/en/dailynews/100828

Carr, S. (2008). State security mobilizes ahead of April 6 general strike, says activist. The Daily News Egypt, p. 1. Retrieved from http://www.masress.com/en/dailynews/102028

Earl, J., \& Kimport, K. (2011). Digitally enabled social change : activism in the Internet age. Cambridge, Mass.: MIT Press.

El-Bey, D. (2010). A vision for youth. Al-Ahram Weekly on line, p. 1. Retrieved from http://weekly.ahram.org.eg/2010/1005/ec6.htm

El-Fiqi, M. (2008). Mission: get bread. Al-Ahram Weekly on line, p. 1. Retrieved from http://weekly.ahram.org.eg/2008/888/ec1.htm

El-Sayed, M. (2008). Virtual politics. Al Ahram, p. 1.

Elyan, T. (2010). April 6 join National Association to collect signatures for political reform. The Daily News Egypt, p. 1. Retrieved from http://www.masress.com/en/dailynews/122771

Escobar, A. (2008). Territories of difference : place, movements, life, redes. Durham: Duke University Press.

Garrido, M. I. (2006). The importance of social movements' networks in development communication : lessons from the Zapatista Movement in Chiapas, Mexico.

Howard, P. N. (2010). The digital origins of dictatorship and democracy : information technology and political Islam. Oxford; New York: Oxford University Press.

Kaplan, A. M., \& Haenlein, M. (2010). Users of the world, unite! The challenges and opportunities of Social Media. Bus. Horiz. Business Horizons, 53(1), 59-68.

Latour, B. (2007). Reassembling the social : an introduction to actor-network-theory. Oxford; New York: Oxford University Press.

Melucci, A. (1994). A Strange kind of newness: What's New in New Social Movements? In E. Laraña, H. Johnston \& J. R. Gusfield (Eds.), New social movements : from ideology to identity. Philadelphia: Temple University Press.

Reem , L. (2008). Heated teachers, cool officials. Al-Ahram Weekly on line, p. 1. Retrieved from http://weekly.ahram.org.eg/2008/913/eg4.htm

Shehab, S. (2011). Time for action. Al Ahram, p. 1. 
Singer, M. (2008). Court orders release of April 6 youths, but lawyers expect they will be detained longer. The Daily News Egypt, p. 1. Retrieved from http://www. thedailynewsegypt.com/court-orders-releaseof-april-6-youths-but-lawyers-expect-they-will-be-detained-longer.html

Singer, M., \& Samaan, M. (2008). April 6 activists stand by detained peers. The Daily News Egypt, p. 1. 